\begin{tabular}{ll}
\hline & Jurnal Sains Materi Indonesia \\
Homepage: http://jusami.batan.go.id
\end{tabular}$\quad$\begin{tabular}{l} 
Akreditasi LIPI \\
$\begin{array}{l}\text { No.: 602/AU3/P2MI-LIPI/03/2015 } \\
\text { Tangal 15 April 2015 } \\
\text { ISSN : 1411-1098 }\end{array}$ \\
\hline
\end{tabular}

\title{
PENGARUH KADAR AIR DAN JENIS TANAH TERHADAP PENYEDIAAN ARUS SISTEM IMPRESSED CURRENT CATHODIC PROTECTION UNTUK PROTEKSI KOROSI PIPA BAJA
}

\author{
Tubagus Noor Rohmannudin, Sulistijono dan Arini \\ Departemen Teknik Material, FTI - ITS \\ Kampus ITS Keputih Sukolilo, Surabaya 60111 \\ E-mail: roma@mat-eng.its.ac.id
}

Diterima: 4 Agustus 2016

Diperbaiki: 4 November 2016

Disetujui: 16 November 2016

\begin{abstract}
ABSTRAK
PENGARUH KADAR AIR DAN JENIS TANAH TERHADAP PENYEDIAAN ARUS SISTEM IMPRESSED CURRENT CATHODIC PROTECTION UNTUK PROTEKSI KOROSI PIPA BAJA. Faktor lingkungan yang menjadi salah satu indikator utama terhadap korosi pada tanah adalah resistivitas dan kadar air tanah. Tujuan penelitian adalah untuk menganalisis pengaruh resistivitas dan kadar air tanah terhadap kebutuhan arus proteksi sistem ICCP pada material pipa API 5L Grade B sebagai katoda yang yang diberi variasi coating (coating seluruhnya, tanpa coating dan cacat gores berbentuk persegi dengan luas $500 \mathrm{~mm}^{2}$ ). Variasi kadar air adalah $0 \%$ (kondisi kering) dan 25\%. Anoda menggunakan grafit, rectifiernya sebagai penyearah arus dan elektroda referensi $\mathrm{Cu} / \mathrm{CuSO}_{4}$ sebagai elektroda acuan. Pengukuran arus proteksi ini dilakukan selama 7 hari dengan pengambilan data setiap hari. Dari hasil penelitian terlihat bahwa dengan bertambahnya kadar air dalam tanah akan menyebabkan nilai resistivitas tanah menurun, karena bertambahnya jumlah air dalam tanah akan mempermudah aliran arus. Nilai resistivitas tanah yang semakin tinggi akan membutuhkan arus proteksi yang rendah karena pada tanah dengan nilai resistivitas tinggi memiliki tahanan yang tinggi (lemah menghantar listrik atau bersifat isolator). Sedangkan dengan kadar air tanah yang tinggi nilai arus proteksi semakin meningkat karena air mempermudah ionisasi elektron dalam tanah sehingga mempermudah aliran arus
\end{abstract}

Kata kunci: Resistivitas tanah, Kadar air, ICCP, Pipa baja

\begin{abstract}
THE EFFECT OF VARIATIONS IN RESISTIVITY AND SOIL WATER CONTENT TOWARDS CURRENT IN IMPRESSED CURRENT CATHODIC PROTECTION SYSTEM AT STEEL PIPE. Corrosion is the main problem of the failure of metal pipe and it is unavoidable from underground piping system. The frequent method that been used for reducing corotion in underground pipe by giving coat and ICCP installation. The environment factor become the most indicator towards ground corotion is the resistivity and soil water content. The purpose of this research are to analyze the resistivity effect and soil water content towards the requirement of ICCP current protection system at metal pipe API 5L Grade B as a chatode that been add with the coating variation (full coating, without coating and square form scratch defect with $500 \mathrm{~mm}^{2}$ wide). The $0 \%$ of water content variation (dry condition) and $25 \%$. We use graphite as an anode and current rectifier and $\mathrm{Cu} /$ $\mathrm{CuSO}_{4}$ electrode as a reference. The measurement of this current protection been held for 7 days with data retrieval everyday. From this research it show us that the increase of soil water content level make the soil resistivity reduce, because the increasing of the water level in the soil can ease the current. The soil resistivity number can be higher but it needs the low current protection, this is all due to the soil with the higher resistivity have the high resistance (too weak to deliver the electric current or isolator). Meanwhile with the high level of soil water content, the number of the current protection will be increase, this is all due to the water can easily absorb the ionisation of the electron in the soil so it can ease the current flow. According to the hypothesis of the authors, the higher of resistivity will make the current of protection will be even lower.
\end{abstract}

Keywords: Soil Resistivity, Water Content, ICCP, Steel pipe 


\section{PENDAHULUAN}

Pada sektor minyak dan gas terdapat jaringan pipa dibawah tanah yang harus sangat diperhatikan karena memiliki peranan yang penting dalam proses produksi maupun distribusi. Pipa onshore umumnya didesain supaya dapat beroperasi 10 tahun hingga 40 tahun. Namun korosi merupakan penyebab utama kegagalan material yang dapat menurunkan kualitas material akibat interaksi dengan lingkungan sekitar sehingga mempercepat umur operasi [1].

Kondisi lingkungan tanah yang ekstrim juga akan menambah kecenderungan terjadinya korosi. Korosi pada tanah merupakan fenomena yang kompleks dengan berbagai variabel yang terkait. Variasi sifat fisik dan karakteristik tanah adalah faktor utama penyebab korosi pada struktur yang terpendam. Oleh sebab itu, perlu adanya perlindungan terhadap korosi. Pelapisan (coating) menjadi salah satu solusi dalam menjaga kestabilan dan penghalang terhadap lingkungan korosif sehingga mengurangi laju korosi atau degradasi logam.

Sering kali saat proses pemasangan struktur atai pipa logam di dalam tanah terdapat benturan atau gesekan pipa logam dengan tanah yang membuat kerusakan pada coating, sehingga perlu dilakukan usaha lain untuk mengendalikan korosi. Salah satu usaha tersebut adalah dengan menggunakan proteksi katodik metode Impressed Current Cathodic Protection (ICCP) [2]. Sistem ICCP ini digunakan untuk melindungi struktur baik yang dicoating dan tidak di-coating. Sistem ini dapat melindungi struktur dengan cara pemberian arus secara paksa yang dapat diatur sesuai kebutuhan dengan tingkat fleksibilitas yang cukup baik.

Penelitian-penelitian sebelumnya telah banyak membahas mengenai kondisi lingkungan dan pengaruh kualitas coating dalam mempengaruhi laju korosi. Namun mengenai resitivitas tanah, kadar air dalam tanah, dan kondisi coating belum dibahas secara spesifik, padahal banyak aplikasi dalam perhitungan laju korosi yang menggunakan variabel tersebut.

Oleh sebab itu pada penelitian ini akan diteliti mengenai kadar air di dalam tanah, nilai resistivitas dan kondisi coating yang akan berpengaruh terhadap kebutuhan arus proteksi korosi pada sistem ICCP didalam tanah.

\section{METODE PERCOBAAN}

\section{Bahan dan Alat}

Bahan dan alat yang digunakan dalam penelitian ini adalah sebagai berikut : pipa API 5L Grade B, anoda Karbon Grafit, Cat Zinc Chromate, tanah dengan jenis yang berbeda, alat ukur resistivitas tanah, elektroda $\mathrm{Cu}-\mathrm{CuSO}_{4}$, dan rectifier.

\section{Cara Kerja}

\section{Preparasi katoda}

Spesimen yang digunakan sebagai katoda adalah pipa logam API 5L Grade B. Pipa dipotong dengan dimensi panjang $100 \mathrm{~mm}$ dan diameter pipa $60 \mathrm{~mm}$. Kemudian pipa tersebut diberi lapis lindung dengan menggunakan zinc chromate yang dicampur dengan thinner B sebanyak dua lapis secara merata. Setelah pemberian lapis lindung, langkah selanjutnya adalah memberi goresan pada lapis lindung atau coating tersebut dengan ukuran dimensi yang berbeda.

Tabel 1. Komposisi kimia API 5L Grade B[3]

\begin{tabular}{cc}
\hline Elemen & Kadar $\%$ \\
\hline Carbon & 0,22 \\
Mangan & 1,2 \\
Phospor & 0,025 \\
Sulfur & 0,015 \\
Titanium & 0,04 \\
\hline
\end{tabular}

\section{Preparasi Anoda}

Anoda yang digunakan adalah grafit. Dipilih grafit dikarenakan tergolong logam mulia dan memiliki laju konsumable yang rendah [4] . Anoda grafit ini dipotong dengan dimensi tebal $13 \mathrm{~mm}$ dan diameter $36 \mathrm{~mm}$.

Tabel 2. Spesifikasi Anoda Grafit [5]

\begin{tabular}{lc}
\hline \multicolumn{1}{c}{ Spesifikasi } & Keterangan \\
\hline Kategori & Impregnated Epoxy Resin $(\mathrm{H})$ \\
Model & M120H \\
Bentuk & Tubular \\
Dimensi & $\mathrm{P}=138 \mathrm{~mm}: \mathrm{d}=26 \mathrm{~mm}$ \\
Masa Pakai & 20 tahun \\
Kompoisi Kimia & $99,8 \%$ Carbon; $0,2 \%$ ash \\
Laju korosi & 0,1-1kg/A.Year \\
\hline
\end{tabular}

\section{Preparasi Media Tanah}

Pada penelitian ini menggunakan media tanah. tanah yang digunakan terdapat lima jenis tanah yaitu, tanah pasir yang memiliki warna abu-abu (tanah pasir kali), tanah rawa, tanah pasir yang memiliki warna hitam pekat, tanah kapur dan tanah humus, kelima jenis tanah tersebut guna untuk memberi variasi resistivitas. Sedangkan variasi kadar air yang digunakan sebesar $0 \%$ (kondisi kering) dan 25\%. Langkah selanjutnya adalah menghitung nilai resistivitas dari setiap jenis tanah tersebut dengan menggunakan metode wenner.

\section{Pengukuran Resivitas Tanah}

Pengukuran resistivitas tanah dilakukan dengan metode wenner. Metode ini memiliki empat buah pin yang terbuat dari batang tembaga yang ditanam di dalam tanah dengan jarak yang sama dalam satu garis lurus. Dua pin terluar (pin 1dan 4) digunakan untuk melewatkan arus sehingga dihubungkan dengan arus yang diseri dengan 
ampermeter yang merupkan elektroda arus. Dua pin yang ditanam ditengah (pin 2 dan 3) dan dihubungkan dengan voltmeter merupakan eletroda potensial untuk mengukur potensial saat dua pin terluar diberi arus. Besar arus dan potensial yang dihasilkan dicacat, kemudian dihitung dengan menggunakan rumus matematika metode wenner seperti Persamaan (1) [5].

$$
\rho=2 \pi \mathrm{a}(\mathrm{V} / \mathrm{I})
$$

Dimana:

$$
\begin{aligned}
& \rho=\text { Resistivitas / tahanan jenis tanah (Ohm-m) } \\
& \mathrm{a}=\operatorname{Jarak} \text { antar pin tembaga }(\mathrm{m}) \\
& \mathrm{V}=\text { Tegangan pada dua pin ditegang (Volt) } \\
& \mathrm{I}=\text { Arus pada dua pin terluar (Ampere) }
\end{aligned}
$$

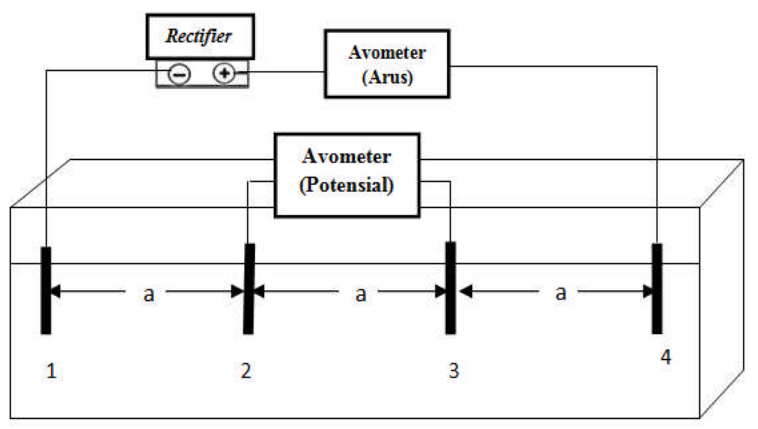

Gambar 1. Skema pengukuran resistivitas tanah

Pengambilan media tanah yang berbeda dan pemberian tambahan kadar air ini dimaksudkan untuk mengetahui nilai resisitivitas tanah tersebut dengan adanya berbedaan kelembaban dan untuk mengetahui tingkat kebutuhan arus proteksi yang dibutuhkan pada lingkungan tanah tersebut.

\section{Pengkondisian Spesimen}

Pengkondisian dilakukan dengan cara imersi dalam media tanah selama 8 hari. Dari 5 variasi resistivitas dan 2 variasi kadar air yang berbeda, masing-masing diletakkan ke dalam 4 box container dengan memberi tanda untuk membedakan media tanah di dalamnya. Selama pengkondisian awal ini, dilakukan juga pengukuran potensial awal setiap katoda untuk membandingkan besar nilai potensial sebelum dan sesudah dilakukan instalasi ICCP.

\section{Pembuatan Rangkaian ICCP}

Katoda dan anoda dihubungkan melalui kabel dengan rectifier sebagai penyearah arus dan digital multitester serta avometer sebagai petunjuk potensial dan arus dalam rangkaian ICCP. Untuk instalasi ICCP, kabel pada pipa dihubungkan ke kutub negatif (-) rectifier dan kabel pada anoda grafit dihubungkan ke kutub positif (+) rectifier.

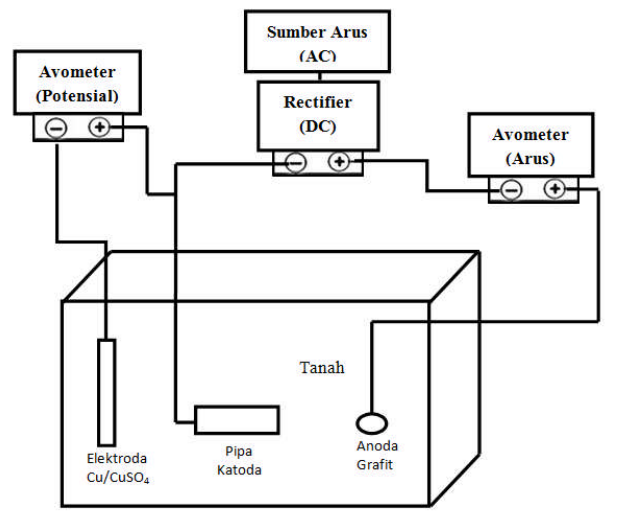

Gambar 2. Skema rancangan ICCP

\section{Pengukuran Arus Proteksi}

Setelah Rangkaian ICCP terpasang, langkah selanjutnya adalah pengukuran kebutuhan arus proteksi dengan menggunakan metode pengukuran half-cell potensial (potensial elektroda setengah sel). Beda potensial yang diukur berdasarkan perbedaan tegangan antara elektroda kerja dengan referensi yang dimasukan kedalam tanah. Elektroda acuan (reference) yang yang digunakan adalah elektroda reference $\mathrm{Cu} / \mathrm{CuSO}_{4}$. Dalam sistem ICCP ini yang menjadi fokus utama sebagai parameter adalah tingkat proteksi yang diperoleh dari potensial korosi. Sehingga arus proteksi dapat diatur sedemikian rupa supaya nilai potensial spesimen berada dalam keadaan terproteksi.

Pengukuran dilakukan dengan menghubungkan kabel pada katoda dengan kutub positif $(+)$ avometer dan menghubungkan elektroda reference dengan kutub negatif (-) avometer [6]. Pengukuran arus proteksi dilakukan selama 7 hari dengan interval setiap hari selama 7 hari [6]. Data yang diambil adalah nilai arus proteksi yang diatur dari rectifier ke katoda untuk mendapat nilai potensial yang dalam level terproteksi yaitu $-850 \mathrm{mV}$ sampai - $1000 \mathrm{mV}$. Pengukuran dilakukan sebanyak 3 kali pengulangan untuk mendapat nilai yang lebih tepat dan diambil nilai rata-rata. Dalam penelitian ini juga dilakukan pengamatan makro setiap spesimen untuk mengetahui perubahan fisik yang terjadi [7].

\section{HASIL DAN PEMBAHASAN}

\section{Hasil Pengukuran Nilai Resistivitas Tanah}

Analisis awal yang dilakukan pada penelitian kali ini adalah mengukur nilai resistivitas tanah dengan menggunakan metode wenner dengan kondisi tanah yang berbeda dan akan diberi perlakuan yang berbeda dengan memberi perbedaan kadar air. Kadar air yang diberikan adalah $0 \%$ dan $25 \%$. Dari hasil pengujian tersebut diperoleh beberapa data untuk pengukuran nilai resistivitas yaitu nilai arus dan potensial. Berdasarkan data yang diperoleh tersebut didapatkan hasil nilai resitivitas setiap jenis tanah dengan 
kadar air yang berbeda, hasil tersebut dapat dilihat pada Tabel 3.

Tabel 3. Nilai resistivitas dengan variasi kadar air

\begin{tabular}{lcc}
\hline \multirow{2}{*}{ Jenis Tanah } & \multicolumn{2}{c}{ Nilai Resistivitas (ohm.m) } \\
\cline { 2 - 3 } & Kadar Air & Kadar Air \\
& $0 \%$ & $25 \%$ \\
\hline Tanah Pasir (Warna Abu-abu) & 1209,32 & 82,46 \\
Tanah Rawa & 1744,47 & 92,36 \\
Tanah Pasir Halus (Warna & 2985,04 & 97,81 \\
Hitam Pekat) & 6165,39 & 123,69 \\
Tanah Kapur & 8040,91 & 326,44 \\
Tanah Humus &
\end{tabular}

Dari hasil pengukuran didapatkan bahwa dalam jenis tanah yang sama, semakin besar nilai kadar air dalam tanah maka akan semakin rendah nilai resistivitasnya. Hal tersebut sesuai dengan Bai Wei (2013), yang mengatakan bahwa setiap peningkatan komposisi air di dalam tanah maka akan mempengaruhi konduktivitas dan resistivitas secara signifikan [8]. Hal tersebut karena air merupakan medium penghantar listrik yang akan mempermudah arus listrik untuk mengalir di dalam tanah sehingga dapat menurunkan daya hambat tanah atau resistivitas tanah terhadap aliran listrik.

\section{Pengkondisian Awal Spesimen}

Pengkondisian awal dilakukan dengan cara imersi spesimen dalam media tanah selama 8 hari sebelum instalasi dengan sistem ICCP [7]. Pengkondisian ini bertujuan untuk merusak lapisan pasif yang terdapat pada permukaan spesimen. Selain itu dilakukan

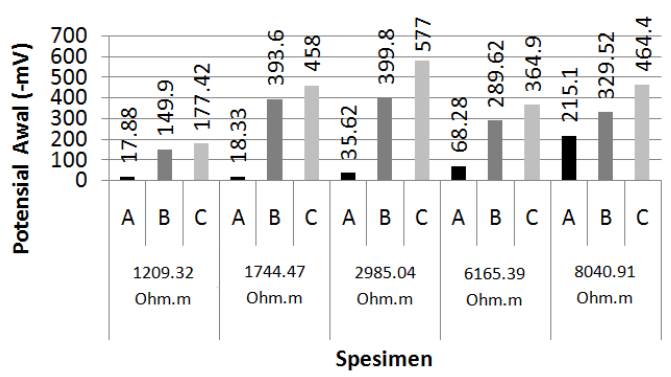

Gambar 3. Grafik hasil nilai potensial awal dalam media tanah dengan kondisi kadar air $0 \%(\mathrm{~A}=$ Full coating, $\mathrm{B}=$ Luas goresan $500 \mathrm{~mm}^{2}$, dan $\mathrm{C}=$ Tanpa coating)

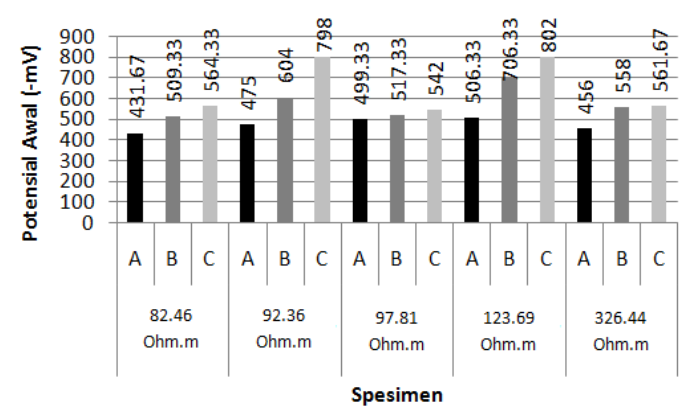

Gambar 4. Grafik hasil nilai potensial awal dalam media tanah dengan kondisi kadar air 25\% (A = Full coating, $\mathrm{B}=$ Luas goresan $500 \mathrm{~mm}^{2}$, dan $\mathrm{C}=$ Tanpa coating). pengukuran potensial untuk mengetahui perbandingan nilai potensial sebelum dan sesudah instalasi ICCP. Pengukuran ini menggunakan avometer dan elektroda reference $\mathrm{Cu} / \mathrm{CuSO}_{4}$.

\section{Pengukuran Arus Proteksi}

Rangkaian ICCP dijalankan dengan mengatur kebutuhan arus sehingga potensial kerja benda berada pada kisaran $-850 \mathrm{mV}$ sampai - $1000 \mathrm{mV}$ dimana baja dapat terproteksi. Hasil pengukuran arus proteksi terhadap nilai resistivitas dan kadar air pada hari ke 7 dapat dilihat pada Tabel 4 dan Gambar 5.

Tabel 4. Nilai arus proteksi masing-masing resisivitas dengan kadar air $0 \%$

\begin{tabular}{ccll}
\hline \multirow{2}{*}{$\begin{array}{c}\text { Resistivitas } \\
\text { (ohm.m) }\end{array}$} & \multicolumn{3}{c}{ Arus Proteksi Spesimen (A) } \\
\cline { 2 - 4 } & $\begin{array}{c}\text { Full } \\
\text { Coating }\end{array}$ & $\begin{array}{l}\text { Goresan } \\
500 \mathrm{~mm}^{2}\end{array}$ & $\begin{array}{c}\text { Tanpa } \\
\text { Coating }\end{array}$ \\
\hline 1209,32 & 0,00009 & 0,000143 & 0,002 \\
1744,47 & 0,00011 & 0,0002 & 0,00193 \\
2985,04 & 0,00007 & 0,00012 & 0,0012 \\
6165,39 & 0,0001 & 0,0002 & 0,00113 \\
8040,91 & 0,000103 & 0,0002 & 0,0093 \\
\hline
\end{tabular}

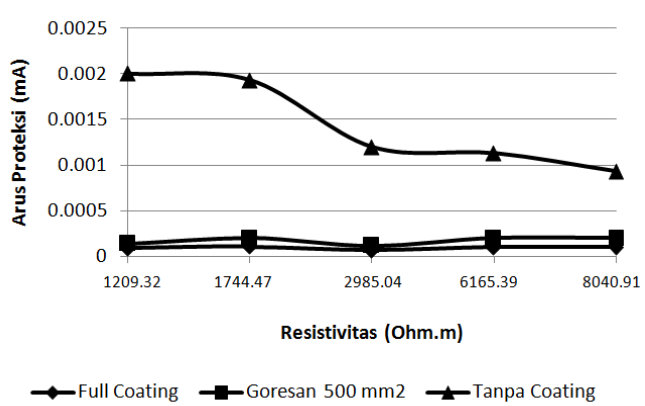

Gambar 5. Grafik perbandingan nilai arus proteksi dengan kadar air $0 \%$.

Berdasarkan data pada Tabel 4 , arus yang dibutuhkan cenderung menurun dengan semakin tingginya nilai resistivitas tanah. Selain itu, dengan semakin besar luas goresan lapis lindung yang kontak langsung dengan lingkungan, maka akan semakin tingi arus proteksi yang dibutuhkan. Hal tersebut terjadi karena adanya daerah pada permukaan logam yang terekspose ke lingkungan sehingga mengakibatkan terjadi reaksi oksidasi atau disebut juga dengan korosi. Pasokan elektron dari rectifier berfungsi untuk menurunkan laju korosi[9]. Oleh sebab itu, pipa dengan luas goresan lapis lindung yang besar membutuhkan arus proteksi yang besar juga karena arus proteksi berbanding lurus dengan laju korosi. Semakin besar laju korosi maka semakin besar juga arus yang dibutuhkan untuk mengendalikan laju korosi tersebut [10].

Dari hasil pengukuran arus proteksi yang didapatkan pada hari ke tujuh, dapat dilihat bahwa dalam kadar air yang sama semakin rendah nilai resistivitas tanah maka semakin tinggi kebutuhan arus yang diberikan pada pipa [11]. Hal ini menunjukkan resitivitas 
Tabel 5. Nilai Arus Proteksi Masing-Masing Resisivitas dengan Kadar Air $25 \%$

\begin{tabular}{lccc}
\hline \multirow{2}{*}{$\begin{array}{c}\text { Resistivitas } \\
\text { (ohm.m) }\end{array}$} & \multicolumn{3}{c}{ Arus Proteksi Spesimen (A) } \\
\cline { 2 - 4 } & $\begin{array}{c}\text { Full } \\
\text { Coating }\end{array}$ & $\begin{array}{c}\text { Goresan } \\
500 \mathrm{~mm}^{2}\end{array}$ & $\begin{array}{c}\text { Tanpa } \\
\text { Coating }\end{array}$ \\
\hline 82,46 & 0,012 & 0,026 & 0,043 \\
92,36 & 0,009 & 0,025 & 0,03 \\
97,81 & 0,003 & 0,006 & 0,0253 \\
123,69 & 0,0021 & 0,0053 & 0,0247 \\
326,44 & 0,002 & 0,0067 & 0,0257 \\
\hline
\end{tabular}

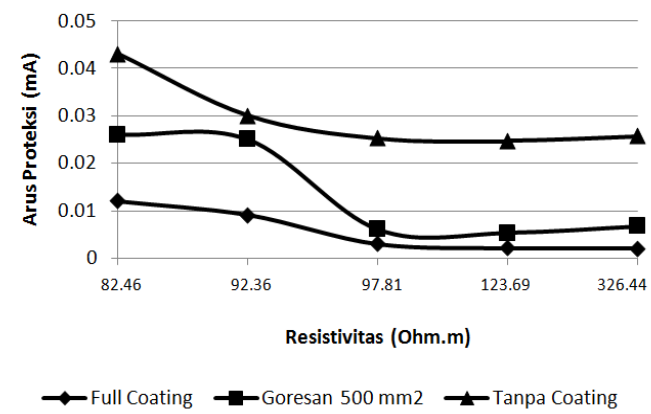

Gambar 6. Grafik perbandingan nilai arus proteksi dengan kadar air $25 \%$.

tanah yang rendah akan menghasilkan tahanan sirkuit yang rendah pula, sehingga sel korosi mampu menghantarkan aliran arus korosi menjadi lebih mudah, akibatnya laju korosi dipercepat sehingga membutuhkan arus proteksi yang tinggi [12].

Pada tanah yang bertekstur lebih halus (tanah humus yang pada umumnya memiliki ukuran partikel $>0,002 \mathrm{~mm}$ ) memiliki partikel yang lebih padat dan kapasitas pori untuk difusi air atau udara lebih sedikit dibandingkan tanah yang memiliki tekstur kasar (pasir yang pada umunya memiliki ukuran partikel $>2 \mathrm{~mm}$ ). Ruang pori pada tanah mengandung air atau gas. Kandungan air atau udara ini berfungsi untuk mempermudah jalannya elektron untuk proses oksidasi atau korosi [13]. Dari uraian tersebut dapat dikatakan bahwa kapasitas pori yang semakin besar (pasir) akan mempermudah jalannya elektron untuk proses oksidasi atau korosi sehingga membutuhkan arus proteksi yang lebih besar.

Selain ukuran partikel tanah, kandungan unsur yang terdapat pada tanah juga mempengaruhi proses oksidasi atau korosi di dalamnya. Pada tanah pasir kandungan yang umum dijumpai adalah kuarsa. Kuarsa ini memiliki sifat tidak mudah bereaksi dengan senyawa kimia lain. Pada tanah rawa, umumnya memiliki kandungan ion klorida yang tinggi yang menyebabkan tingginya tingkat oksidasi. Hal ini berdampak pada nilai resistivitas tanah menjadi rendah. Ion klorida ini mudah bereaksi dengan permukaan logam Fe dengan membentuk senyawa $\mathrm{FeC}_{12}$. Senyawa $\mathrm{FeC}_{12}$ merupakan senyawa korosi. Sedangkan pada tanah kapur, umunya mengandung magnesium dan calcium. Pada tanah humus mengandung elemen yang hampir sama dengan tanah kapur yaitu calcium, magnesium dan potassium yang elemen tersebut akan membentuk oksida yang tidak larut. Endapan yang tidak larut tersebut akan menghasilkan lapisan protektif pada permukaan logam sehingga melindungai logam dari lingkungan. Hal ini akan mengurangi aktivitas korosi dan nilai arus proteksi yang dibutuhkan rendah. Sehingga dapat dikatakan bahwa tanah jenis ini memiliki nilai resistivitas yang tinggi.

Dari Gambar 6 tersebut juga dapat dilihat dengan bertambahnya kadar air dalam tanah akan menyebabkan nilai kebutuhan arus proteksi akan semakin tinggi pula. Hal tersebut dikarenakan banyaknya air pada tanah maka akan semakin mudah ionisasi elektrolit dalam tanah sehingga memudahkan aliran arus akibat aktivitas korosi dan kadar air dalam tanah berhubungan dengan konsentrasi oksigen dalam tanah. Kandungan oksigen pada tanah secara langsung berhubungan dengan ruang pori dan kandungan air [14]. Pada tanah yang kering, difusi oksigen menjadi lebih cepat. Perubahan kering ke basah akan meningkatkan laju korosi daripada lingkungan tanah yang konstan. Konsentrasi oksigen meningkat dengan fluktuasi air dan udara, kapasitas pori yang besar maka akan memudahkan penetrasi air ke dalam tanah sehingga meningkatkan kelembaban tanah dan bersifat lebih korosif [11].

Dari hasil pengamatan makro spesimen terlihat adanya peningkatan pola korosi pada kenaikan kadar air di dalam media tanah. Gambar 8 menunjukkan kondisi spesimen pada media tanah dengan kadar air $25 \%$. Pada gambar tersebut terlihat lapisan berwarna coklat kemerahan (produk korosi) terbentuk di permukaan spesimen. Produk korosi pada Gambar 8 terlihat lebih banyak jika dibandingkan dengan Gambar 7. Selain itu, Gambar 7 dan Gambar 8 juga menunjukkan bahwa peningkatan kadar air dapat menurunkan nilai resistivitas tanah.

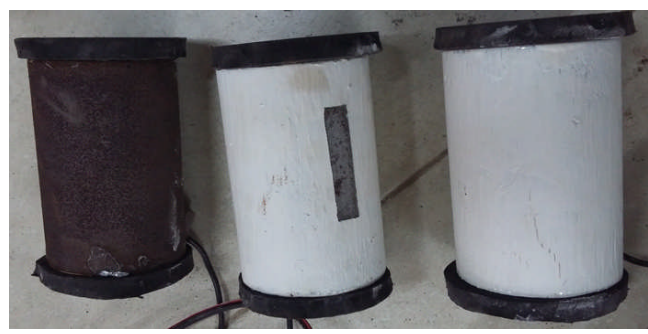

Gambar 7. Kondisi spesimen di dalam media tanah pasir dengan kandungan air $0 \%$ dan resistivitas 1209,32 Ohm.m

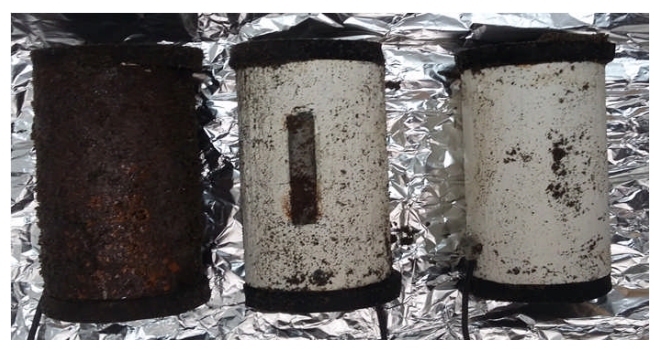

Gambar 8. Kondisi spesimen di dalam media tanah pasir dengan kandungan air $25 \%$ dan resistivitas 82,46 Ohm.m 


\section{KESIMPULAN}

Berdasarkan hasil penelitian yang telah dilakukan, dapat disimpulkan bahwa pengaruh dari resistivitas tanah yang semakin besar, akan menyebabkan kebutuhan arus proteksi yang semakin kecil, Hal tersebut dikarenakan resistivitas dengan nilai yang tinggi memiliki tahanan yang tinggi pula (atau bersifat isolator) sehingga arus proteksi yang dibutuhkan kecil.

Pengaruh kadar air yang semakin meningkat, maka kebutuhan arus proteksi akan semakin besar. Hal tersebut karena dengan bertambahnya jumlah kadar air dalam tanah akan mempermudah aliran arus karena air merupakan media penghantar listrik.

\section{UCAPAN TERIMAKASIH}

Ucapan terimakasih disampaikan kepada DIKTI, LPPM ITS dan Departemen Teknik Material FTI-ITS yang mendukung terlaksananya penelitian dan penulisan.

\section{DAFTAR ACUAN}

[1]. E. Bardal. Corrosion and Protection. Trondheim: Norway, 2003.

[2]. A. Wiludin dan H. Supomo. "Analisa Teknis dan Ekonomis Penggunaan ICCP (Impressed Current Cathodic Protection) Dibandingkan dengan Sacrificial Anode dalam Proses Pencegahan Korosi.” Jurnal Teknik. vol. 2, no. 1, 2013.

[3]. “API Specification 5L”. Forty Second Edition. 2012.

[4]. Callister, William. D. Jr. "Fundamentals of Materials Science and Engineering." Seventh Edition. USA: John Wiley \& Sons Inc, 2012.

[5]. A.W.Peabody. "Control of Pipeline Corrosion." Edited by Ronald L Bianchetti. Texas: NACE International the Corrosion Society, 2001.

[6]. NACE. "Control of External Corrosion on Undergrounf or Submerged Metallic Piping Systems." Available at http//www.nace.org [2014]
[7]. W. Bai, L Kong and A, Guo. "Effect of Physical properties on Electrical Conductivity of Compacted Lateritic Soil." Jurnal of Rock Mechanics and Geotechnical Engineering, 2013.

[8]. M. N. Shobah, T. N. Rohmannudin, dan Sulistijono. "Pengaruh Goresan Lapis Lindung dan Salinitas Air Laut Terhadap Arus Proteksi Sistem Impressed Current Cathodic Protection (ICCP) pada Pipa API 5L Grade B.” Jurnal Teknik Pomits, vol. 1, no. 1, pp 1-6. 2014.

[9]. Alwi, S. Sarwito dan I. R. Kusuma. “Analisa Teknis Dan Ekonomis Perubahan Sacrificial Anode Menjadi Impressed Current Cathodic Protection Untuk Meminimalisir Korosi Pada Lambung Kapal.” Jurnal Teknik Pomits, vol. 1, no. 1, pp 1-5. 2012.

[10]. B. Prameswari. "Studi Efektifitas Lapis Galvanis terhadap Ketahanan Korosi Pipa Baja ASTM A53 di Dalam Tanah." Universitas Indonesia. Indoneisa 2008.

[11]. Aditya, dkk. "Pengaruh Lebar Goresan Pada Lapis Lindung Polietilena dan pH Tanah Terhadap Proteksi Katodik Anoda Tumbal Pada Baja AISI 1045 di Lingkungan Tanah Rawa.” 2012

[12]. F. P. Ardiansyah, Sulistijono dan T. N. Rohmannudin. "Pengaruh $\mathrm{pH}$ Tanah dan Cacat Gores Lapis Lindung Terhadap Kebutuhan Arus Proteksi dengan Menggunakan Sistem Impressed Current Cathodic Protection (ICCP) Untuk Baja AISI 1045." Jurnal Teknik Pomits, vol. 2, no. 1, 2013.

[13]. Sarwani dan P. Bayu. "Perancangan Sistem Proteksi Katodik Anoda Korban pada Pipa Baja. Studi Kasus Pipa PGN yang Berada di PT. NIPPON SOKUBAI INDONESIA." Jurnal Ilmiah dan Teknologi. vol. IX, no. 24, Juni, 2013.

[14]. F. Afriani, Komalasari dan Zultinar. "Proteksi Katodik Metoda Anoda Tumbal Untuk Mengendalikan Laju Korosi." Jurnal Fteknik, vol. 1, no. 2, 2014. 